Based on the modern understanding of scientific and technological progress, systemic automation caused the training of a specialist of a new type with a qualitatively higher level of professional training. This approach involves the transition from extensive to intensive methods of teaching physics and technical disciplines on the basis of information and digital technologies. On the basis of the conducted analysis, a model of principles for the formation of a methodical system for the development of information and digital competence of future computer technology specialists in the teaching of physics and technical disciplines has been developed.

The article defines the conceptual framework for the development of information and digital competence of future computer technology specialists. To achieve this goal, the following methods were used: analysis of theoretical sources on the problem of developing competencies, studying and generalizing advanced pedagogical experience. Certain components and a model are the basis for creating the structure and content of professional training of a future specialist in the specialty "Vocational Education (Computer Technology)". Compliance with these principles ensures the selection of optimal forms, methods and teaching aids, as well as the content of physics and technical disciplines in the preparation of future computer technology specialists for the development of their digital information competence.

Keywords: conceptual foundations, information and digital competency, teaching methods, physics and technical disciplines, digitalization, future specialists of computer technologies.

DOI: https://doi.org/10.31392/NZ-npu-142.2019.27

УДК 373.2.064.1

Феднова I. М.

\title{
ОСОБЛИВОСТІ ПРОСВІТНИЦЬКОї ДІЯЛЬНОСТІ ВИХОВАТЕЛЯ ЗАКЛАДУ ДОШКІЛЬНОЇ ОСВІТИ
}

У статті розглянуто особливості просвітницької діяльності вихователя закладу дочкільної освіти. Уточнено суть концептуального поняття "просвітницька діяльність". Виокремлено основні риси просвітництва як суспільної течії - альтруїзм та доступність подання й комфортність отримання інформачії суб'єктами взаємодії. Визначено аспекти просвітницької діяльності, ї̈ різні форми, через які відбувається надання інформації населенню, принципи організації просвітницької діяльності. Визначено мету просвітницької діяльності закладу дошкільної освіти - підвищення культури батьків та надання допомоги у вихованні дітей. Виокремлено й схарактеризовано основні форми реалізачії просвітнищької діяльності у закладах дошкільної освіти, найбільш ефективними з яких визначено застосування інформаційного інтернет-простору та залучення батьків до інтерактивної діяльності у святкових тематичних заходах.

Для комфортного розвитку дитини у двох додаткових системах - домашній та ЗДО існує потреба організації просвітницько-консультативної діяльності ЗДО (закладів дошкільної освіти) для батьків дошкільнят, метою якої має стати ознайомлення дорослих 3 елементарними знаннями про особливості вікового розвитку дитини; надання їм допомоги у виріменні особистих иілей щуодо виховання нащадків, щүо призведе до узгодженості виховних виливів обох систем.

У статті уточнюється поняття "просвітницька діяльність"; визначено основні риси просвітницької діяльності як суспільної течії; виокремлено ї̈ основні функиїі, визначено мету, особливості організащії, форм та методів реалізащії просвітницької діяльності у закладах 
дошкільної освіти.

Метою просвітницької діяльності закладів дошкільної освіти, організованої для батьків вихованщів, є підвищення культури батьків та надання допомоги у вихованні дітей.

Ключові слова: просвітницька діяльність, заклад дошкільної освіти, батьки вихованців, риси просвітнищтва, батьківська культура.

Сучасний стан інформатизації суспільства та високий ступінь зайнятості працюючих батьків виявляє серйозну проблему: недостатню або фахово-хибну поінформованість батьків дітей у особливостях педагогічного впливу на розвиток особистості дитини. Зазначена проблема поглиблюється тим, що сучасні молоді батьки, що користуються послугами ЗДО, внаслідок зайнятості, не мають достатньо часу на розвиток педагогічних знань, а отже, їхній вплив на дитину визначається більшою мірою інтуїтивними потягами, ніж свідомими цілями. Зважаючи на те, що у ЗДО дитина підлягає цілеспрямованому педагогічно обґрунтованому з погляду вікової доцільності та змістових видів розвитку впливу фрахівців, актуальною стає проблема стресу дитини, яка змушена постійно пристосовуватись як до режиму дитячого садку, так і домашніх правил життєдіяльності. Отже, для комфортного розвитку дитини у двох додаткових системах - домашній та ЗДО - існує потреба організації просвітницько-консультативної діяльності ЗДО для батьків дошкільнят, метою якої має стати ознайомлення дорослих з елементарними знаннями про особливості вікового розвитку дитини; надання їм допомоги у вирішенні особистих цілей щодо виховання нащадків, що призведе до узгодженості виховних впливів обох систем.

Метою cmammi визначаємо уточнення поняття "просвітницька діяльність"; визначення основних рис просвітницької діяльності як суспільної течії; виокремлення її основних функцій; визначення мети, особливостей організації, фрорм та методів реалізації просвітницької діяльності у закладах дошкільної освіти.

Готовність вихователів ЗДО до просвітницько-консультативної діяльності батьків учнів насамперед передбачає уточнення суті концептуального поняття: “просвітницька діяльність".

У довідкових джерелах поняття "просвітницька діяльність" представлене в аспекті змісту просвітництва як суспільної течії, що сприяла розповсюдженню передових ідей та знань у різних суспільних верствах населення у різні роки існування держави. Філософський енциклопедичний словник поняття “просвітництво" наділяє функцією зміни поглядів населення, що ґрунтуються на релігійному або політичному авторитеті, такими котрі випливають із потреб людського розуму та можуть витримати критику з боку кожного окремого індивіда [5].

У наукових працях просвітництво представлено, перш за все, як діяльність видатних особистостей, зокрема, братств Києво-Могилянської академії, видатних діячів В. Каразіна, В. Капніста, В. Рубана, Я. Козельського та ін. Дослідники акцентують увагу на тому, що в історії держави просвітницька діяльність була зорієнтованою, перш за все, на неосвічені верстви населення, що спричиняло необхідність адаптувати інформацію для ії розуміння конкретним соціальним товариством. Н. Фрадкіна зауважує на різноманітті фрорм та методів просвітницької діяльності слобідської інтелігенції: недільних 
школах, позашкільних професійних загальноосвітніх закладах для робітників, товариств з поширення грамотності серед населення (у формах видавничої діяльності), закладах просвітницько-естетичного напрямку (товариств любителів хорового співу, музичного гуртку), наукових та науково-технічних товариствах (медичному, технічному, історико-фрілологічному тощо) [7].

Отже, основними рисами просвітницької діяльності можна визначити альтруїзм у взаємодії із населенням, збудження інтересу людей до нових ідей, доступність надання та комфортність отримування інформації, (через реалізацію у певних формах і методах її представлення).

Сучасні підходи до просвітницької діяльності визначають ії різноплановість за змістом. Зокрема, найбільш активно просвітницька діяльність для населення організовується з метою поглиблення знань або формування споживчих умінь за змістом галузей економіки, політики, права, медицини, фізичної культури тощо. У дослідженні І. Лисенко висвітлюються особливості просвітницької діяльності організаційних психологів, основними видами якої автор визначає індивідуальні (доступ до відповідної літератури, профрільних сайтів, аудіо та відео ресурсів); фронтальні (лекції) та групові (тренінги, рольові ігри, постійно діючі семінари). При цьому цікавим видається підхід до організації фронтальних фрорм, ефективність яких науковець вбачає в тому, що отримувана в присутності інших людей інформація засвоюється краще, оскільки на їі сприйняття, аналіз та осмислення впливають емоційні реакції оточення. Цей ефект пов'язаний із поняттям фрасилітації, що виявляється у більш успішній діяльності особистості за умови їі перебігу у присутності спостерігачів (інших суб'єктів діяльності) [4]. І. Фольварочний аналізує просвітницьку діяльність учителя фрізичної культури. При цьому автор зосереджується на ідеї популяризації здорового способу життя особистості через залучення до просвітницької діяльності як школярів, так і їхніх батьків. Науковець актуалізує увагу на конкретних формах просвітницької діяльності для дорослої аудиторії (показові виступи юних спортсменів, створення куточку спортивної слави у межах шкільного музею, оперативних таблиць та фотозвітів спортивних заходів та їх результатів, куточку для батьків 3 порадами про раціональний режим життя учнів тощо, організація спільних із батьками заходів типу “Мама, тато, я - спортивна сім'я"), що не лише дають уявлення про зміст конкретної інформації, але й активізують мотивацію щодо залучення у презентовану діяльність, викликають бажання бути причетним до неї [6].

Отже, аналіз досліджень 3 проблеми просвітницької діяльності представляє можливим визначити її основні функції: надання знань з окремих питань для конкретно визначеної аудиторії (при цьому має бути ураховано особливості сприйняття спільнотою інформації); організація інтерактивних заходів з конкретної проблеми з метою формування у населення певних практичних умінь та способів миследіяльності.

Дослідники у галузі педагогіки дошкілля зауважують, перш за все, на формуванні через просвітництво у батьків дітей культури батьківства, що розуміється як система батьківської діяльності, яка виділяє ступінь активності батька й матері в процесі виховання дітей у сім'ї [3]. Основною платформою для організації зазначеного процесу має стати система ЗДО, яка може як забезпечити професійне надання просвітницько-консультативних послуг 
батькам вихованців, так і представити нові ідеї щодо розвитку сучасних дітей у мінливих умовах суспільних перетворень для широкої аудиторії. Крім підвищення культури батьків, метою просвітницької діяльності ЗДО науковці визначають також допомогу у вихованні дітей за умови особистісного впливу батьків на їх виховання [1].

Просвітництво батьків дітей дошкільного віку, за думкою Г.Борин, має відтворювати зміст педагогічних, логопедичних, медичних та психологічних проблем у вихованні та розвитку дитини відповідного віку [1]. При цьому варто зауважити, що, якщо для батьків дітей раннього та молодшого дошкільного віку найбільш актуальними будуть питання, що стосуються медичного (здоров'язбережувального) та психологічного аспектів розвитку, то батьки вихованців старшого дошкільного віку цікавляться насамперед питаннями підготовки дитини до школи, а тому методистам та вихователям ЗДО слід запропоновувати для них інформацію, що стосується розвитку мовленнєвого апарату дошкільника (із включенням питань логопедії) та педагогічних аспектів впливу на розвиток психомоторної сфрери дитини. Крім того, для батьків старших дошкільників важливості проблема усвідомлення дитиною моральності поведінки, а тому актуальності набуває інформація про розвиток моральних якостей дитини, рівні норми у реакціях на аморальну поведінку людей в окремих ситуаціях.

В аспекті організації батьківського просвітництва у системі ЗДО слід зупинитись на найбільш прийнятних формах його реалізації. Так, А Залізняк форми батьківської просвіти розрізняє: за місцем проведення (у сім'ї, на нейтральній території, у закладі, на вулиці); характером спілкування (безпосереднім та опосередкованим, усним, письмовим, за допомогою технічних засобів зв'язку, із поєднанням видів спілкування); участю членів сімей (вся сім'я, обидва батьки, мати чи батько з дитиною, матері, батьки); кількістю сімей (індивідуальні, групові, масові або колективні); тривалістю (разові, короткочасні, постійнодіючі, пульсуючі); змістом (формування знань та умінь; батьківських якостей і рис; правильного ставлення до дитини); метою (обслуговуючі, реабілітаційні, профрілактичні, супроводжуючі); впливом на сім'ю (ознайомлюючі, спонукальні, перетворювальні) [2].

Погоджуючись із такою детальною характеристикою фрорм та методів просвітницької діяльності, зауважуємо, що в аспекті урахування тотальної зайнятості батьків, все ж таки більш ефективним буде організація їх просвітництва через застосування інформаційного інтернет-простору - для розсилання важливої для батьків інформації, а також через залучення батьків до інтерактивної діяльності у межах організації та проведення святкових тематичних заходів.

Висновок. Отже, поняття “просвітницька діяльність" розглядається нами як діяльність з поінформування конкретних суспільних ланок населення 3 важливих для них питань. Основними рисами просвітницької діяльності $\epsilon$ альтруїзм та доступність подання й комфортність отримання інформації суб'єктами взаємодії. Функціонально просвітницька діяльність призначена сорормувати у населення певні практичні уміння та способи миследіяльності, а тому її організатори мають орієнтуватись на інтерактивні фрорми взаємодії 3 аудиторією. 
Метою просвітницької діяльності закладів дошкільної освіти, організованої для батьків вихованців, є підвищення культури батьків та надання допомоги у вихованні дітей. При цьому найбільш ефективними фрормами організації просвітництва батьків дітей визначено застосування інформаційного інтернетпростору та їх залучення до інтерактивної діяльності у святкових тематичних заходах.

\section{Використана література :}

1. Борин Г. В. Організаційно-педагогічні умови підготовки майбутніх вихователів до роботи 3 батьками дітей раннього віку: автореф. дис. ... канд. пед. наук. ; спец. : 13.00 .04 - Теорія і методика професійної освіти. Тернопіль, 2009. 20 с.

2. Залізняк А. М. Форми та методи взаємодії з батьками старших дошкільників [Електронний pecypc]. URL : https://dspace.udpu.edu.ua/jspui/bitstream/pdf

3. Кушнір В. М. Формування культури батьківства в традиціях української педагогіки. Дошкільна освіта в сучасному освітньому просторі : Проблеми та перспективи : збірник тез за матеріалами Всеукр. науково-практичної конференції (23 листопада 2017 року) / гол. ред. В. Г. Кузь. Умань : ВПЦ "Візаві", 2017. 88 с. С. 36-40. [Електронний ресурс]. Режим доступу : https://dspace.udpu.edu.ua/jspui/bitstream/6789/7592/1/pdf

4. Лисенко I. М. Особливості консультативної діяльності психолога в юридичній сфері. Міжнародний науковий форум: соиіологія, психологія, педагогіка, менеджмент: збірник наукових праць. Вип. 9. Київ : Вид-во НПУ імені М. П. Драгоманова, 2012. С. 178-184.

5. Философский словарь / под ред. И. Т. Фролова. Москва, 1986. 588 с.

6. Фольварочний I. В. Просвітницька діяльність у популяризації фізичної культури. Педагогічний прочес: теорія і практика. 2014. Вип. 3. С. 60-62. [Електронний ресурс]. URL: http://nbuv.gov.ua/jpdf/pptp_2014_3_14.pdf

7. Фрадкіна Н. В. Просвітницька діяльність інтелігенції на Слобожанщині в кінці XIX - на початку XX століття як феномен культури : автореф. дис. ... канд. філософських наук. Харків, 2007. 20 с.

\section{References:}

[1] Boryn, H. V. (2009). Orhanizatsiino-pedahohichni umovy pidhotovky maibutnikh vykhovateliv do roboty z batkamy ditei rannoho viku : avtoref. dys. ... kand. ped. nauk. ; spets. : 13.00 .04 - Teoriia i metodyka profesiinoi osvity. Ternopil, $20 \mathrm{~s}$.

[2] Zalizniak, A. M. Formy ta metody vzaiemodii z batkamy starshykh doshkilnykiv [Elektronnyi resurs]. URL : https://dspace.udpu.edu.ua/jspui/bitstream/pdf

[3] K ushnir, V. M . (2017). F ormuvannia kultury batkivstva v tradytsiiakh ukrainskoi pedahohiky. Doshkilna osvita v suchasnomu osvitnomu prostori : Problemy ta perspektyvy : zbirnyk tez za materialamy V seukr. naukovo-praktychnoi konferentsii (23 lystopada 2017 roku) / hol. red. V. H. K uz. U man : V PT s "V izavi", 88 s. S. 36-40. [Elektronnyi resurs]. Rezhym dostupu : https://dspace.udpu.edu.ua/jspui/bitstream/ $6789 / 7592 / 1 / p d f$

[4] Lysenko, I. M. (2012). Osoblyvosti konsultatyvnoi diialnosti psykholoha v yurydychnii sferi. Mizhnarodnyi naukovyi forum: sotsiolohiia, psykholohiia, pedahohika, menedzhment: zbirnyk naukovykh prats. V yp. 9. K yiv : Vyd-vo N PU imeni M. P. Drahomanova, S. 178-184.

[5] Fylosofskyi slovar (1986). / pod red. Y. T. Frolova. M oskva, $588 \mathrm{s.}$

[6] Folvarochnyi, I. V. (2014). Prosvitnytska diialnist u populiaryzatsii fizychnoi kultury. Pedahohichnyi protses: teoriia i praktyka. Vyp.3. S.60-62. [Elektronnyi resurs]. URL: http://nbuv.gov.ua/jpdf/pptp_2014_3_14.pdf

[7] Fradkina, N. V. (2007). Prosvitnytska diialnist intelihentsii na Slobozhanshchyni v kintsi XIX - na pochatku XX stolittia yak fenomen kultury : avtoref. dys. ... kand. filosofskykh nauk. K harkiv, 20 s.

ФЕДНовА И.Н. Особенности просветительской деятельности воспитателя дошкольного образовательного заведения.

В статье рассмотрены особенности просветительской деятельности воспитателя дошкольного образовательного заведения. Уточнена суть конщептуального понятия 
"просветительская деятельность". Выделены основне черты просвещения как общественного движения - альтруизм, доступность предоставления и комфорт получения информации субъектами взаимодействия. Определены аспекты просветительской деятельности, ее разные формы, посредством которых предоставляется информация населению, принципь организачии просветительской деятельности Определена ичель просветительской деятельности дошкольного образовательного заведения: повымение культуры родителей и предоставление им помощи в воспитании детей. Выделены и охарактеризованы основные формы реализаџии просветительской деятельности в дошкольных образовательных заведениях, наиболее эффективнылми из которых определены применение информачионного интернет-пространства и привлечение родителей к интерактивной деятельности в праздничных тематических мероприятиях.

Для комфортного развития ребенка в двух дополнительных системах - домашней и ДОЗ существует потребность организаџии просветительско-консультативной деятельности ДОЗ (дошкольного образовательного заведения) для родителей дошкольников, иелью которой должно стать ознакомление взросльх с элементарными знаниями об особенностях возрастного развития ребенка; оказание им помощи в решении личных задач по воспитанию потомков, что приведет к согласованности воспитательных воздействий обеих систем. В статье уточняется понятие "просветительская деятельность"; определены основные черты просветительской деятельности как общественного течения; вылелены ее основные функиии; определены ичели, особенности организачии, форм и методов реализации просветительской деятельности в учреждениях дошкольного образования. Целью просветительской деятельности учреждений дошкольного образования, организованной для родителей воспитанников, является повышение культуры родителей и оказание помощчи в воспитании детей.

Ключевые слова: просветительская деятельность, дошкольное образовательное заведение, родители виспитанников, черты просвітительства, родительская культура.

FEDNOVA I. M. Peculiarities of a teacher's professional activity in preschool education.

The article deals with the peculiarities of a teacher's educational activity in the institution of preschool education. The main definition of the concept "educational activity" is considered. It is singled out the basic features of enlightenment as a social trend that is altruism and availability of presentation, the convenience of obtaining information by members of interaction. The aspects of educational activity, its various forms with which the information is provided to the population, the principles of educational activities organization are determined. It is defined the purpose of the educational activity of the preschool education institution that is to raise the culture of parents and assisting in the upbringing of children. The main forms of educational activity realization in pre-school establishments are outlined and characterized, the most effective of which is the use of informational Internet space and involvement of parents in interactive activities in festive thematic.

For the comfortable development of the child in two additional systems - home and DOS - there is a need to organize educational and advisory activities of the DOS (preschool educational institution) for parents of preschool children, the aim of which should be to familiarize adults with basic knowledge about the features of age development of the child; assisting them in solving personal tasks of raising offspring, which will lead to a coordination of the educational effects of both systems. The article clarifies the concept of "educational activities"; identified the main features of educational activities as a social movement; its main functions are highlighted; The goals, features of the organization, forms and methods of implementing educational activities in preschool institutions are defined. The aim of the educational activities of pre-school education institutions, organized for parents of pupils, is to increase the culture of parents and to assist in raising children.

Keywords: educational activity, institution of preschool education, parents of pupils, features of education, parenting culture. 